\title{
EVALUATION OF MICONAZOLE NITRATE PERMEABILITY THROUGH BIOLOGICAL MEMBRANE FROM DERMAL SYSTEMS
}

\author{
MAGDALENA BÎRSAN ${ }^{1,3}$, ANA CATERINA CRISTOFOR ${ }^{2}$, PAULA ANTONOAEA $^{3}$, \\ NICOLETA TODORAN ${ }^{3 *}$, NELA BIBIRE ${ }^{4}$, ALINA DIANA PANAINTE ${ }^{4}$, ROBERT $^{3}$ \\ ALEXANDRU VLAD $^{3}$, MIHAELA GRIGORE $^{5}$, ADRIANA CIURBA $^{3}$ \\ 1"Grigore T. Popa” University of Medicine and Pharmacy of Iași, Departament of Pharmaceutical Sciences II, 16 \\ Universității Street, Iași, Romania \\ 2 “Grigore T. Popa” University of Medicine and Pharmacy of Iași, Medical Department III, 16 Universității Street, \\ Iași, Romania \\ ${ }^{3}$ University of Medicine, Pharmacy, Sciences and Technology of Târgu Mureș, Department of Pharmaceutical Technology \\ and Cosmetology, 38 Gh. Marinescu Street, Târgu Mureș, Romania \\ 4 "Grigore T. Popa" University of Medicine and Pharmacy of Iași, Departament of Pharmaceutical Sciences I, 16 \\ Universității Street, Iași, Romania \\ 5 "Grigore T. Popa” University of Medicine and Pharmacy of Iași, Department of Obstetrics and Gynaecology, 16 \\ Universității Street, Iasi, Romania
}

*corresponding author: nicoleta.todoran@umfst.ro

Manuscript received: April 2019

\begin{abstract}
The development of pharmaceutical products with miconazole nitrate (MN) can bring various benefits to patients of whom fungal infections are resistant to classic antifungal formulas. In medical practice, dermal systems, in the form of polymeric films, represent an alternative to other medical products. The proposed dermal films contain hydroxyethyl cellulose (HEC) as a hydrophilic and bioadhesive matrix polymer, with the addition of polyethylene glycol (PEG) as a low-absorption promoter, so that the antifungal have a slow penetration towards the dermis. This study aims to evaluate the in vitro permeability of MN through biological membrane (pig ear skin) at $\mathrm{pH} 7.4$, during its release from two polymeric films. In vitro pig ear skin permeation studies indicated that the amount of the drug released after $24 \mathrm{~h}$ was $40 \%$ in the case of formulation FI and $32 \%$ in the case of formulation FII from the initial dose $(40 \mathrm{mg})$. The concentration of $40 \% \mathrm{MN}$ released can be considered an appropriate antifungal dose, with the benefit of being accumulated in the stratum corneum where it is maintained for up to 4 days.
\end{abstract}

\section{Rezumat}

Dezvoltarea de forme farmaceutice cu nitrat de miconazol (MN) poate aduce numeroase beneficii pacienților care au dezvoltat rezistență clinică la formulările antifungice clasice. În practica medicală, sistemele dermice formulate ca filme polimerice reprezintă o alternativă de administrare față de alte produse medicamentoase. Filmele dermice propuse conțin hidroxietilceluloză, un polimer bioadeziv formator de matriţă, în asociere cu polietilenglicol ca promotor cu proprietăţi moderate de penetrare cutanată, astfel încât substanța activă să poată penetra lent țesutul cutanat. Acest studiu își propune evaluarea in vitro a permeației MN prin membrană biologică (piele de ureche de porc) la $\mathrm{pH} 7,4$ din două tipuri de filme polimerice. Studiile de permeație in vitro prin membrană biologică indică o eliberare de $40 \%$ a substanței active după 24 de ore (FI), respectiv 32\% (FII). Cantitatea de MN eliberată (40\%) asigură eficiența antifungică, substanţa activă acumulându-se în stratul cornos unde se menține până la 4 zile după prima aplicare.

Keywords: miconazole nitrate, dermal films, hydroxyethyl cellulose matrix, Franz cell method

\section{Introduction}

The increasing number of stress conditions caused by the diversification of activities conducted in modern society, associated with the occurrence of the corresponding pollution factors and the diversity of microbial agents, in particular caused by the increased mobility of people all over the world, led, in addition to the appearance of new diseases, to the occurrence and the diversification of fungal infections. The development of pharmaceutical forms with miconazole nitrate (MN) for external use can bring various benefits to patients presenting resistance to classic antifungal forms because of the fact that the active drug lasts longer in the tissue, acting as a slow release product [7, 8]. Repeated administration leads to an accumulating effect of multiple doses in the stratum corneum, which causes the disappearance of fungal infection $[6,28]$. Miconazole nitrate is an antifungal drug that inhibits the synthesis and the incorporation of ergosterol in the fungal cell's membrane as a result of blocking sterol14 $\alpha$-demethylase, a cytochrome P450 dependent 
enzyme, with a key role in biosynthesis of ergosterol. Accumulation of methyl-steroids affects the function of membrane phospholipids and inhibits certain enzymatic membrane dependant systems, like ATPase and enzymatic transport systems, with inhibition of growth and development of fungi. It also acts by affecting the permeability of the fungi membrane, selectively inhibiting RNA and DNA precursors and its mucopolysaccharides $[6,7,19]$. Transdermal forms offer several important advantages over conventional administration routes $[2-4,10,14,19,21]$. The skin acts as a barrier and the optimization of the release of the drug through this barrier is often the first step towards optimizing the efficiency of such pharmaceutical preparations $[12,23,27]$. The pharmaceutical product is placed on the skin for topical or systemic action, depending on the penetration properties (with local dermal effect through crossing the corneum layer of epidermis) and permeation capacity (with transdermal effect through absorption into the systemic circulation). It's known that the miconazole nitrate is retained in the skin layers up to 4 days after the first administration. The greatest challenge for such types of pharmaceutical forms with miconazole nitrate is to remain for as much as possible at the stratum corneum level. A transdermal administration can ensure an optimal concentration of the drug throughout the treatment period. The proposed dermal films contain hydroxyethyl cellulose (HEC) as a bioadhesive matrix forming polymer, with the addition of polyethylene glycol (PEG) as a low-absorption promoter so that the antifungal does not penetrate too much towards the dermis. The main reason for choosing HEC as a bioadhesive matrix forming polymer was its ability to adhere to mucous membrane and human skin, providing stability to the film [26], and the lack of toxicity [5, $15,18]$. HEC with an apparent viscosity of 4500 $6500 \mathrm{mPa} \cdot \mathrm{s}$ is highly water-soluble and practically insoluble in ethanol, being used as a hydrophilic gel former. HEC is a hydrophilic polymer with fast dissolution, and it forms gels at $1.5 \%-2 \%$, which exhibit good bioadhesiveness and yield capacity [5].
Although a series of mathematical assumptions have been issued describing drug diffusion through the skin, due to the complexity of the cutaneous organ, it is very difficult to describe a perfect mathematical model [20]. The unanimous acceptance is that the transportation of drugs through the skin takes place through passive diffusion. In vitro availability tests with the classical Franz cell can be performed under both static and dynamic diffusion conditions. Contact with the donor compartment is made through a diffusion membrane that simulates the transfer through the stratum corneum. According to FDA SUPAC-SS 1997, synthetic membranes with different compositions are accepted: polysulfone, cellulose acetate, cellulose nitrate or polyfluoroethylene, with a diameter close to that of the diffusion cell [11]. Nylon represents a polyamide derivative [24] very commonly used for preliminary tests. OECD Guidance (Organization for Economic Cooperation and Development) [22] considers that the use of a biological human skin membrane is the golden standard in assessing transcutaneous absorption in the design of the in vitro penetration study [9, 13]. Other types of biological membranes can be used instead, but it should be taken into account that they behave differently from human skin [16, 17].

The proposed study evaluates the in vitro permeation of the antifungal from dermal films through a biological membrane $(\mathrm{Mb})$ using the Franz cell. The pig ear skin is a membrane more similar to human epidermis at $\mathrm{pH}$ of body fluids [1].

\section{Materials and Methods}

\section{Materials}

Miconazole nitrate (MN) was purchased from Sigma Aldrich Inc (Germany). Hydroxyethyl cellulose $250 \mathrm{M}$, NatrosolTM 250M (HEC, viscosity of 4500 - 6500 $\mathrm{mPa} \cdot \mathrm{s}$ ) from Ashland (Germany), Polyethylene glycol 400 (PEG 400) from Sigma Aldrich Inc. (Germany), ethanol from Stireco LTH (Romania) (Table I).

\begin{tabular}{lcccc} 
& & \multicolumn{2}{c}{$\begin{array}{c}\text { Table I } \\
\text { Type and composition of samples proposed for analysis }\end{array}$} \\
\hline \multicolumn{1}{c}{ Ingredient } & Abbreviation & \multicolumn{2}{c}{ Formula $\%$} & Function \\
\cline { 2 - 4 } & & FI & FII & Antifungal \\
\hline Miconazole nitrate & MN & 5.00 & 5.00 & Film forming \\
\hline Hydroxyethyl cellulose 250 M & HEC & 2.00 & 3.00 & Co-solvent \\
\hline Polyethylene glycol 400 & PEG $_{400}$ & 1.00 & 1.00 & Plasticizer, drug solubilizer, humectant \\
\hline Ethanol & - & 10.00 & 10.00 & Solvent \\
\hline Ultrapure water & - & 82.00 & 81.00 & \\
\hline
\end{tabular}

Films preparation technique. MN was first dissolved in alcohol with stirring at $500 \mathrm{rpm}$ for 5 minutes and after we added PEG, distilled water and HEC during constant stirring. The air bubbles were eliminated from the structured gel by maintaining the fluid phase for 25 minutes in the ultrasound bath. The resulting composition was poured into circular plates (diameter of $9.8 \mathrm{~cm}$ ) which were then kept to dry at $40^{\circ} \mathrm{C}(24 \mathrm{~h})$. The obtained films were used in the study after 48 hours of preservation at $20^{\circ} \mathrm{C}$, protected from humidity [13]. 
Products in form of dermal systems, proposed in study. Samples of $2.54 \mathrm{~cm}^{2}$ containing $40 \mathrm{mg} \mathrm{MN}$ in polymeric matrices of HEC ( $2 \%$ in FI and $3 \%$ in FII), with polyethylene glycol - PEG 400 were prepared in form of films with thickness of $0.23 \mathrm{~mm}$ (FI) and $0.30 \mathrm{~mm}$ (FII), by casting and solvent evaporation technique. Preparation of biological skin used as the diffusion membrane. The biological membrane $(\mathrm{Mb})$ consisted of skin from pig ears collected from a local abattoir. According to literature specifications, in order to preserve the integrity of the skin barrier function, the pig ears were removed immediately after slaughter from the carcass and washed with water [17]. After removing the hair yam, the ears were individually wrapped in aluminium foil and frozen at $-26^{\circ} \mathrm{C}$ for a maximum of 6 months. It is known that the freezing preservation method will not influence the permeability properties of the biological skin subsequently used as the diffusion membrane in the in vitro tests $[1,7,11]$. The biological membranes were prepared by excising from the freshly defrosted pig ears spherical surfaces ( $1.8 \mathrm{~cm}$ diameter). The excess fat and the cartilage were carefully removed, and then the membranes were kept for 30 minutes in the buffer phosphate $\mathrm{pH} 7.4$ [13].

Determination of in vitro release and diffusion through the biological membrane profiles. The in vitro permeation of $\mathrm{MN}\left(\mathrm{mg} / \mathrm{cm}^{2} * \mathrm{~h}\right)$ was determined by Franz cell method [12] in the following conditions: cell of $14 \mathrm{~mL}$, phosphate buffer at $\mathrm{pH} 7.4$ with $0.045 \%$ sodium lauryl sulphate, $32 \pm 0.5^{\circ} \mathrm{C}$, assessing the MN from acceptor sample of $5 \mathrm{~mL}$, at $273 \mathrm{~nm}$ (Spectrometer UVD 3200, Labomed Inc., USA). The analysed sample consisted in disk shaped films with diameter of $1.8 \mathrm{~cm}$ (surface of $2.54 \mathrm{~cm}^{2}$ ), deposited on the studied membrane $(\varnothing 25 \mathrm{~mm})$ and maintained in the donor compartment under occlusive conditions throughout the determination period.

Data interpretation and statistical analysis. GraphPad Prism 6 software was used running: linear regression followed by the runs tests, the Pearson correlation (r), area under the curve (AUC), unpaired t test followed by F test and Anova followed by Tukey's multiple comparison tests. Mean and standard deviation (SD) were calculated as statistical descriptors and statistical significance was set at $\mathrm{p}<0.05$ with confidence interval of $95 \%$ [25].

In a previous study, MN permeation was assessed in vitro through the Franz cell from dermal films using a synthetic membrane [7]. The values of antifungal permeation through synthetic membranes (Ms Teknokroma, $0.45 \mu \mathrm{m}$ ) were compared with those of biological membranes ( $\mathrm{Mb}$ - pig ear skin, $<1 \mathrm{~mm}$ ).

\section{Results and Discussion}

The in vitro permeation curves of $\mathrm{MN}$ (40 mg/sample) released from two types of HEC matrices as new systems intended for dermal application (FI, FII) were determined over a period of $24 \mathrm{~h}$ (Figure 1), by using in the Franz cell samples of $2.54 \mathrm{~cm}^{2}$ deposited on diffusion membranes.

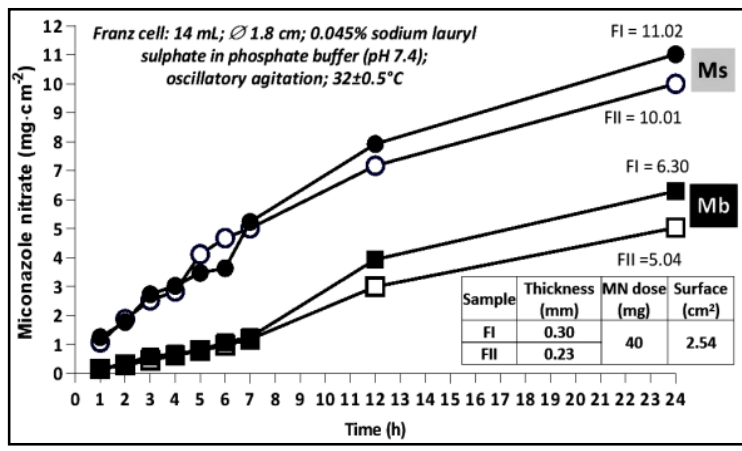

Figure 1.

The in vitro permeation curves determined from experimental data

The permeation determined through the two membranes used is the result of two initial successive and then simultaneous processes, namely: the release of $\mathrm{MN}$ by dissolution and diffusion from HEC/PEG matrix, followed by the membrane crossing of $\mathrm{MN}$ by molecular diffusion through the membrane pores, thus resulting in a cumulative process whose rate depends on both stages (Table II), but one of which is usually more limited.

\begin{tabular}{lcccc}
\hline Linear regression of release curves & FI - Mb & FII - Mb & FI - Ms & FII - Ms \\
\hline Slope \pm Standard Error $(95 \% \mathrm{CI})$ & $0.2848 \pm 0.02041$ & $0.2236 \pm 0.01155$ & $0.4335 \pm 0.03616$ & $0.3813 \pm 0.03885$ \\
Y-intercept & $-0.3419 \pm 0.1995$ & $-0.1989 \pm 0.1129$ & $1.371 \pm 0.3535$ & $1.655 \pm 0.3797$ \\
X-intercept & 1.20 & 0.89 & -3.16 & -4.34 \\
\hline R square & 0.9653 & 0.9817 & 0.9535 & 0.9323 \\
\hline P value & $<0.0001$ & $<0.0001$ & $<0.0001$ & $<0.0001$ \\
Deviation from zero & Significant & Significant & Significant & Significant \\
\hline P value (runs test) & 0.2619 & 0.3452 & 0.6429 & 0.0714 \\
Deviation from linearity & Not significant & Not significant & Not significant & Not significant \\
\hline \multirow{2}{*}{ Equation } & $\mathrm{Y}=0.2848 * \mathrm{X}-$ & $\mathrm{Y}=0.2236 * \mathrm{X}-$ & $\mathrm{Y}=0.4335 * \mathrm{X}+\mathrm{Y}=0.3813 * \mathrm{X}+$ \\
& 0.3419 & 0.1989 & 1.371 & 1.655 \\
\hline
\end{tabular}


Permeation through the biological membrane. The $\mathrm{R}$ square coefficient of the regression lines (Table II) indicates a good determination (of $96-98 \%$ ), with the MN permeation rate of 0.28 (FI) and 0.22 (FII) $\mathrm{mg} / \mathrm{cm}^{2} / \mathrm{h}$, through $\mathrm{Mb}$. In quantitative terms, it was found that $\mathrm{MN}$ reached a flow through $\mathrm{Mb}$ of 6 $\mathrm{mg} / \mathrm{cm}^{2}$ (FI) and $5 \mathrm{mg} / \mathrm{cm}^{2}$ (FII), respectively, which represents $40 \%$ (FI) and 32\% (FII) of the initial dose (40 mg) of the sample. On a first evaluation of the results, $40 \%$ of $\mathrm{MN}$ released seems not to be a satisfactory percentage, but if we report to the published data in witch MN has been shown to accumulate in the stratum corneum where it is maintained for up to 4 days [24], this percentage can be considered an appropriate dose for a possible antifungal activity. Moreover, same published data show that repeated application multiplies the dose maintained under the stratum corneum, leading to the elimination of the mycotic infection $[6,19]$.

Permeation through the biological vs. synthetic membranes. The amount of MN permeated in $24 \mathrm{~h}$ through $\mathrm{Mb}$ was determined almost exclusively by the contact time between the sample and the membrane, as the Pearson $r$ have the highest values $(0.9825$ FI, 0.9908 - FII) which shows a strong correlation (h $v s . \mathrm{mg} / \mathrm{cm}^{2} \mathrm{MN}$ permeated), compared with Ms. In these later cases, the Pearson $r$ values of 0.9765 FI and 0.9655 - FII indicate there are some other factors which affect the permeation process. Comparing all cases, it appears that the formulation FII (3\% HEC) is more suitable than FI ( $2 \%$ HEC) for further studies which involve biological membranes.

Influence of polymeric matrix on permeation process. Area under the permeation curves (AUC) was calculated for the period of $1 \mathrm{~h}$ to $24 \mathrm{~h}$ and had the following values (mean $\pm \mathrm{SD}, \mathrm{n}=3$ ): $78.61 \pm 4.3(\mathrm{FI}-\mathrm{Mb})$, $62.44 \pm 5.4$ (FII-Mb) and 164.5 \pm 9.2 (FI-Ms), $152.7 \pm$ 8.5 (FII-Ms). AUC-FI vs. AUC-FII shows statistically significant differences only for $\mathrm{Mb}(\mathrm{p}=0.0154$; unpaired $t$ test, confidence interval of $95 \%$ ), case in which the variance was insignificant (Anova one way, Tukey's test) (Table III). The rate of MN permeation $\left(\mathrm{mg} / \mathrm{cm}^{2} / \mathrm{h}\right)$, expressed by the slope of the regression line (Table I), was significantly lower through $\mathrm{Mb}$ (0.28 - FI, 0.22 - FII) than through Ms (0.43 - FI, 0.38 - FII), with time-lag (h) only in the Mb case (1.2 - FI, 0.89 - FII), according to the calculated data in the Table IV.

Table III

Statistical comparison of the AUCs variance

\begin{tabular}{lcc}
\hline \multicolumn{1}{c}{ Unpaired t test of AUC: FII vs. FI } & Mb & Ms \\
\hline $\mathrm{p}$ value & 0.0154 & 0.1781 \\
$\mathrm{p}$ value summary & $*$ significant & not significant \\
Significantly different $(\mathrm{p}<0.05)$ ? & Yes & No \\
One- or two-tailed $\mathrm{p}$ value & two-tailed & two-tailed \\
Difference between means & $-16.17 \pm 3.985$ & $-11.8 \pm 7.232$ \\
95\% Confidence interval & -27.24 to -5.105 & -31.88 to 8.278 \\
$\mathrm{R}$ squared (eta squared) & 0.8045 & 0.3996 \\
\hline $\mathrm{F}, \mathrm{DFn}$, Dfd $(\mathrm{F}$ test $)$ & $1.577,2,2$ & $1.171,2,2$ \\
$\mathrm{p}$ value & 0.7761 & 0.921 \\
$\mathrm{p}$ value summary & not significant & not significant \\
\hline
\end{tabular}

Table IV

Statistical comparison of the regression lines variance

\begin{tabular}{lccccc}
\hline Tukey's multiple comparisons test & $\begin{array}{c}\text { Mean } \\
\text { differences }\end{array}$ & $\mathbf{9 5 . 0 0 \%}$ CI of differences & Significant/Summary & $\begin{array}{c}\text { Adjusted p } \\
\text { value }\end{array}$ \\
\hline FI-Mb $v$ s. FI-Ms & -85.89 & -104.6 to -67.19 & Yes & $* * * *$ & $<0.0001$ \\
FI-Mb $v$ s. FII-Ms & -74.09 & -92.79 to -55.39 & Yes & $* * * *$ & $<0.0001$ \\
FII-Mb $v$ s. FI-Ms & -102.1 & -120.8 to -83.36 & Yes & $* * * *$ & $<0.0001$ \\
FII-Mb $v$ s. FII-Ms & -90.26 & -109 to -71.56 & Yes & $* * * *$ & $<0.0001$ \\
\hline FI-Mb $v$ s. FII-Mb & $\mathbf{1 6 . 1 7}$ & $\mathbf{- 2 . 5 2 7}$ to 34.87 & No & no significance & $\mathbf{0 . 0 9 2 1}$ \\
\hline FI-Ms $\boldsymbol{v s .}$ FII-Ms & $\mathbf{1 1 . 8}$ & $\mathbf{- 6 . 8 9 7}$ to 30.5 & No & no significance & $\mathbf{0 . 2 5 7 0}$ \\
\hline F***
\end{tabular}

\section{Conclusions}

The biggest challenge for formulators is to transport the active substance to the desired site for a targeted action. Compared to the synthetic membrane, the biological membrane reduces to almost half the in vitro permeation of $\mathrm{MN}$ released from polymeric matrices consisting in HEC-PEG of 2:1 (FI) or 3:1
(FII). The differences found between the two analysed dermal systems are insignificantly influenced by HEC content, which means the permeation variation could be due to the thickness difference between the membranes $(0.45 \mu \mathrm{m}-\mathrm{Ms},<1 \mathrm{~mm}-\mathrm{Mb})$, the PEG slightly content variation and/or the influence of PEG on the biological membrane, as it was used in formulations both as plasticizer and as promoter of absorption. The 
formulation FII (3\% HEC) is more suitable than FI ( $2 \%$ HEC) for further studies which involve biological membranes, to optimize the composition by design of experiment and the factorial analysis.

\section{Conflict of interest}

The authors declare no conflict of interest.

\section{References}

1. Abd E, Yoisef SA, Pastore MN, Telaprolu K, Mohammed YH, Namjoshi S, Grice JE, Roberts MS, Skin models for the testing of transdermal drugs. Clin Pharmacol., 2016; 8: 163-176.

2. Abruzzo A, Nicoletta FP, Dalena F, Cerchiara T, Luppi B, Bigucci F, Bilayered buccal films as childappropriate dosage form for systemic administration of propranolol. Int J Pharm., 2017; 531(1): 257-265.

3. Agut J, Palacín C, Sacristán A, Ortij J, Inhibition of ergosterol synthesis by sertaconazole in Candida albicans. Arzneim Forsch., 1992; 42(5A): 718-720.

4. Ahmed TA, El-Say KM, Mahmoud MF, Samy AM, Badawi AA, Miconazole Nitrate Oral Disintegrating Tablets: In Vivo Performance and Stability Study. AAPS Pharm Sci Tech., 2012; 13(3): 760-771.

5. Amiri A, Yu A, Webster DC, Ulven CA, Bio-Based Resin Reinforced with Flax Fiber as Thermorheologically Complex Materials. Polymers, 2016; 8(4):153-160.

6. Bergamo VZ, Donato RK, Dalla Lana DF, Donato KJ, Ortega GG, Schrekker HS, Fuentefria AM, Imidazolium salts as antifungal agents: strong antibiofilm activity against multidrug-resistant Candida tropicalis isolates. Lett Appl Microbiol., 2015; 60(1): 66-71.

7. Bîrsan M, Apostu M, Todoran N, Antonoaea P, Rusu A, Ciurba A, Development of dermal films containing Miconazole Nitrate. Molecules, 2018; 23(7): 1640: 1-12.

8. Bîrsan M, Vieriu M, Bibire N, Cojocaru I, Inflence of Hydroxypropyl Methylcellulose on Flowing and Swelling Parameters in Biomucoadhesive Tablets with Miconazole Nitrate. Rev Chim (Bucharest), 2017; 68(10): 2346-2349.

9. Cojocaru V, Ranetti AE, Hinescu LG, Ionescu M, Cosmescu C, Poștoarcă AG, Cinteza LO, Formulation and evaluation of in vitro release kinetics of $\mathrm{Na}_{3} \mathrm{CaDTPA}$ decorporation agent embedded in microemulsion-based gel formulation for topical delivery. Farmacia, 2015; 63(5): 656-664.

10. De Luca L, Naturally occurring and synthetic imidazoles: their chemistry and their biological activities. Curr Med Chem., 2006; 13(1): 1-23.

11. Dinu Pirvu C, Hlevca C, Ortan A, Prisada R, Elastic vesicles as drug carriers through the skin. Farmacia, 2010; 58 (2):128-135.

12. Graham P, Browne L, Capp A, Fox C, Graham J, Hollis J, Nasser E, Randomized, paired comparison of No-Sting Barrier Film versus sorbolene cream (10\% glycerine) skin care during postmastectomy irradiation. Int J Radiat Oncol Biol Phys., 2004; 58(1): 241-246.
13. Guidance for Industry, Nonsterile Semisolid Dosage Forms, Scale-Up and Postapproval Changes: Chemistry, Manufacturing, and Controls; In Vitro Release Testing and In Vivo Bioequivalence Documentation. 1997; Food and Drug Administration. SUPAC-SS.

14. Heeres J, Meerpoel L, Lewi P, Conazoles. Molecules, 2010; 15(6): 4129-4188.

15. Herkenne C, Naik Y, Kalia YN, Hadgraft J, Guy $\mathrm{RH}$, Pig ear skin ex vivo as a model for in vivo dermatopharmacokinetic studies in man. Pharm Res., 2006; 23(8): 1850-1856.

16. Rădulescu FS, Voicu VA, Stănescu AA, Miron DS, Shah VP, Correlation between rheology, in-vitro release and in-vivo performance of topical dosage forms. DISSO ASIA 2014 International Symposium.

17. Jacobi U, Kaiser M, Toll R, Mangelsdorf S, Audring H, Otberg N, Sterry W, Lademan J, Porcine ear skin: an in vitro model for human skin. Skin Res Technol., 2007; 13(1): 19-24.

18. Maya Jacob J, Sabu T, Biofibres and biocomposites. Carbohydr Polym., 2008; 71(3): 343-364.

19. Marichal P, Vanden Bossche H, Mechanisms of resistance to azole antifungals. Acta Biochim Pol., 1995; 42(4): 509-516.

20. Mitragotri S, Anissimov YG, Bunge AL, Frasch HF, Guy RH, Hadgraft J. Kasting GB, Lane ME, Roberts MS, Mathematical models of skin permeability: An overview. Int J Pharm., 2011; 418(1): 115-129.

21. Morales JO, Brayden DJ, Buccal delivery of small molecules and biologics: of mucoadhesive polymers, films, and nanoparticles. Curr Opin Pharmacol., 2017; 36: 22-28

22. OECD, Guidance Notes on Dermal Absorption. Series on Testing and Assessment, No. 156. ENV/JM/MONO (2011)36, 18-Aug-2011.

23. Panainte AD, Popa G, Pamfil D, Butnaru E, Vasile C, Tartau LM, Gafitanu C, In vitro characterization of polyvinyl alcohol/chitosan hydrogels as modified release systems for bisoprolol. Farmacia, 2018; 66(1): 44-48.

24. Simon A, Amaro MI, Healy AM, Cabral LM, de Sousa VP, Comparative evaluation of rivastigmine permeation from a transdermal system in the Franz cell using synthetic membranes and pig ear skin with in vivo-in vitro correlation. Int J Pharmaceut., 2016; 512(1): 234-241.

25. Todoran N, Antonoaea P, Rusu A, Ciurba A, Bîrsan M, Rédai E, DSC and FT-IR Analysis for the Formulation of Dermal Films with Meloxicam in Bioadhesive Polymeric Matrices. Rev Chim (Bucharest), 2018, 69(12): 3692-3697.

26. Touitou E, Barry BW, Enhancement in Drug Delivery. CRC Press, Taylor \& Francis Group, LLC, 2019.

27. Udeanu DI, Albu Kaya MG, Ghica MV, Marin S, Marin Maria Minodora, Kaya DA, Popa L, DinuPîrvu C, Anti-inflammatory drug-loaded biopolymeric spongious matrices with therapeutic perspectives in burns treatment. Farmacia, 2018; 66(5): 783-790.

28. Vanden Bossche H, Dromer F, Improvisi I, LozanoChiu M, Rex JH, Sanglard D, Antifungal drug resistance in pathogenic fungi. Med Mycol., 1998; 36(Suppl 1): 119-128. 